\title{
COMPARISON OF ZIDOVUDINE COMBINATION AND TENOFOVIR COMBINATION ON THE EFFECTIVENESS OF THERAPY AND SIDE EFFECTS IN HIV/AIDS PATIENTS IN RSAL MINTOHARDJO
}

\author{
PHIHANIAR INSANIPUTRI ${ }^{1}$, SUDIBYO SUPARDI ${ }^{2}$, RETNOSARI ANDRAJATI ${ }^{1 *}$
}

${ }^{1}$ Department of Pharmaceutical Chemistry, Faculty of Pharmacy, Universitas Indonesia, Depok, Indonesia. ${ }^{2}$ National Institute of Health Research and Development, Ministry of Health Republic Indonesia, Jakarta, Indonesia. Email: andrajati@farmasi.ui.ac.id

Received: 20 April 2017, Revised and Accepted: 13 July 2017

\section{ABSTRACT}

Objectives: Tenofovir-based therapy is a newly adopted first-line HIV/AIDS therapy regimen in Indonesia that is replacing the stavudine-based regimen. However, zidovudine-based regimens remain the first-line therapy for patients with HIV/AIDS. This study aimed to compare the effectiveness and incidence of adverse effects with hemoglobin $(\mathrm{Hb})$ in both zidovudine- and tenofovir-based regimens in HIV/AIDS patients at Mintohardjo Hospital.

Methods: We used a cross-sectional comparative research design. The data analyzed were medical records of all HIV/AIDS patients treated through 2015.

Results: The sample included 75 patients in the zidovudine group and 53 patients in the tenofovir group. Wilcoxon signed-rank tests indicated that both combinations of therapy were effective in improving CD4+ cells. Initial CD4+ cell counts $\leq 200$ cells $/ \mathrm{mm}^{3}$ were 4.55 times better at increasing CD4+ cell counts when compared with an initial CD4+ > 200 cells $/ \mathrm{mm}^{3}$. Chi-square results showed that both treatment combinations affected the decrease in $\mathrm{Hb}$. Patients using the zidovudine combination had 4.59 times greater risk for a Hb decrease compared with the tenofovir combination.

Conclusions: Zidovudine- and tenofovir-based regimens had similar effectiveness in increasing CD4+ cell counts, but the tendency to cause anemia in tenofovir-based regimens was less than that of the zidovudine-based regimens.

Keywords: HIV/AIDS, Antiretroviral, Zidovudine, Tenofovir, CD4+, Side effects.

(C) 2017 The Authors. Published by Innovare Academic Sciences Pvt Ltd. This is an open access article under the CC BY license (http://creativecommons. org/licenses/by/4. 0/) DOI: http://dx.doi.org/10.22159/ajpcr.2017.v10s5.23107

\section{INTRODUCTION}

The number of new HIV positive patients in Indonesia for the 3-year period from 2010 to 2012 was steady, but this number increased significantly from 2013 to 2014. Provinces with the highest number of new HIV positive cases were DKI Jakarta, East Java, and West Java [1].

HIV infection has been considered as a chronic illness since the availability of highly active antiretroviral treatments (HAART). The therapy provided has been a combination of three or more drugs and has been proved to improve quality of life, life expectancy, decrease rate of resistance, and further decrease mortality to AIDS related causes [2]. The recommended first-line therapy is a combination of zidovudine/stavudine with lamivudine and nevirapine/efavirenz [3]. Zidovudine was the backbone of HAART therapy, but anemia has been one of its side effects. Agarwal et al. (2010) found that 5-10\% of anemia cases were caused by the use of zidovudine. Therefore, patients with a history of anemia have been given stavudine instead of zidovudine, but stavudine has irreversible and dangerous side effects, such as lipodystrophy, lipoatrophy, peripheral neuropathy, and lactate acidosis [4].

Due to its side effects, stavudine is no longer recommended for use by the WHO. Stavudine was replaced by tenofovir, which was formerly a second-line therapy [5]. Tenofovir has shown fewer side effects compared to either stavudine or zidovudine [6]. The combination therapy with tenofovir has also shown better immunological and virological effectiveness compared with zidovudine and stavudine [6]. Nevertheless, tenofovir has side effects that include kidney disorders, which could result in renal damage (nephrotoxicity) [6].
One parameter that can be used to determine the antiretroviral effectiveness of a patient's immune response is the number of CD4+ cells. A significant increase in the CD4+ cell count of 50-150 cells $/ \mathrm{mm}^{3}$ during the $1^{\text {st }}$ year of therapy signals an adequate therapy response [7]. The standard of therapy and management for HIV/AIDS infections in Indonesia refers to the WHO standards. This therapy has become a government program and is free of charge. The first-line antiretroviral therapy used in combination is zidovudine and lamivudine with efavirenz/nevirapine [8]. In Indonesia, the use of tenofovir as a stavudine replacement began in 2012 .

Indonesia has many hospitals that are used as referral hospitals for HIV/ AIDS infections. One of these is Mintohardjo Hospital (RSAL), which has its own polyclinic for HIV/AIDS patients called Polyclinic Teratai. This polyclinic began providing integrated services for HIV/AIDS patients in 2005. Approximately 100-200 patients are treated in Lotus poly every month. This study aimed to compare the effectiveness of the combination therapy of zidovudine and tenofovir, which promotes the increase in CD4+ cells and to monitor any adverse effects in HIV/AIDS patients in Mintohardjo Hospital.

\section{METHODS}

This research was conducted at the Polyclinic Teratai Mintohardjo Hospital (RSAL) in March-June 2016. The research design used was a cross-sectional comparative study. The population in this study included the medical records of all HIV/AIDS patients in the outpatient clinic who received antiretroviral therapy through 2015. The total sample size was 128 samples, with 75 zidovudine-based regimens and 53 tenofovir combinations. The inclusion criteria were a complete medical record, $\geq 20$ years of age, taking antiretroviral therapy for 
6 months in 2015, and the patient had received a zidovudine-based regimen (a combination of zidovudine/lamivudine/nevirapine or efavirenz) or a tenofovir-based regimen (a combination of tenofovir/ lamivudine/nevirapine or efavirenz). We evaluated full medical record data, including medical record number, name, age, gender, status, risk factors, initial CD4+ cell count, final CD4+ cell count, and laboratory examination data (hemoglobin $[\mathrm{Hb}]$, serum glutamic oxaloacetic transaminase [SGOT], serum glutamic pyruvic transaminase [SGPT], urea, and creatinine)

Data analyses were performed by Chi-square tests to determine the significance of the antiretroviral combination of zidovudine and tenofovir on CD4+ cell count increases and any adverse effects. Other factors affecting the dependent variable were analyzed by Chi-square bivariate tests and multivariate logistic regression tests.

\section{RESULTS}

\section{Sociodemographic characteristics}

Patients on the zidovudine-based regimen included 59 (78.7\%) males, similar to the tenofovir-based regimen, which was also male dominated, with 31 males (58.5\%). Almost all HIV/AIDS patients in RSAL Mintohardjo were in the productive age range of $18-40$ years. This age range included 57 patients $(76.0 \%)$ in the zidovudine group and 44 patients $(83.0 \%)$ in the tenofovir group.

Most patients (50 patients; $66.7 \%$ ) in the zidovudine group had a high school education, results that were similar to the tenofovir group that had 30 patients $(56.6 \%)$ who were high school graduates. Most of the patients were in the navy or another military branch in both the zidovudine group (36 patients; $48.0 \%$ ) and the tenofovir group (30 patients; $56.6 \%$ ).

In the zidovudine group, the majority of patients ( 45 patients; $60.0 \%$ ) were married, and similar findings were observed in the tenofovir group (32 patients; 60.4\%). Almost all HIV/AIDS patients contracted the HIV/AIDS infection through sexual intercourse. In the zidovudine group, 45 patients $(62.7 \%)$ were infected through sexual contact, while in the tenofovir group, 31 patients $(58.5 \%)$ were infected in this manner.

\section{Clinical characteristics}

In the zidovudine group, 18 patients $(24 \%)$ started therapy with CD4+ cell counts above 300 cells $/ \mathrm{mm}^{3}$. However, in the tenofovir group, 20 patients $(37.7 \%)$ started therapy with a CD4+ cell count $<50$ cells $/ \mathrm{mm}^{3}$. In general, the HIV/AIDS patients experienced weight loss before the initiation of therapy, and fluctuations in weight tended to increase each month. In the zidovudine group, 41 patients (54.7\%) did not lose weight, and in the tenofovir group, 35 patients (66.0\%) did not lose weight.

The most frequent opportunistic infection in the HIV/AIDS patients was pulmonary tuberculosis, with 28 patients $(37.3 \%)$ in the zidovudine group and 26 patients (49.1\%) in the tenofovir group. This was followed by oral candidiasis, with 13 patients $(17.3 \%)$ in the zidovudine group, and 14 patients $(26.4 \%)$ in the tenofovir group. In this study, the majority of HIV/AIDS patients were in stage 2, based on the WHO clinical stages, which included 56 patients (43.8\%).

Almost all HIV/AIDS patients (105 patients; 82\%) had a high obedience to therapy. Based on the results of this study, data were obtained from the patients who had undergone treatment for 4-6 months in
50 patients (66.7\%) of the zidovudine group and 25 patients (47.2\%) in the tenofovir group. However, patients who had undergone treatment for $>6$ months included 25 patients (33.3\%) in the zidovudine group and 28 patients $(52.8 \%)$ in the tenofovir group. In RSAL Mintohardjo, tenofovir treatment was still relatively new because its use had only started in early 2015 as a stavudine substitute.

Cotrimoxazole was the most medicine used, with 44 patients (58.7\%) in the zidovudine group and 40 patients $(75.5 \%)$ in the tenofovir group. Antituberculosis drug (TB drugs) became the second most widely used therapy for patients, with 27 patients (36.0\%) in the zidovudine group and 25 patients $(47.2 \%)$ in the tenofovir group.

\section{Comparison of zidovudine- and tenofovir-based regimens on} therapeutic effectiveness

Wilcoxon signed rank analyses showed significant differences in initial CD4+ cell counts and final CD4+ cell counts. This was stated by the value of $\mathrm{p}=0.000$. In the zidovudine group, as many as 54 patients had an increase in $\mathrm{CD} 4+$ cell count, and 21 patients had a decrease from the initial CD4+ cell count. In the tenofovir group, 41 patients had an increase in CD4+ cell count, 9 patients had a decrease, and 3 patients had no change in CD4+ cell count (Table 1).

\section{Comparison of zidovudine- and tenofovir-based regimens on side} effects

Based on the results of the Chi-square tests, there were no significant influences between the zidovudine and tenofovir groups on the increases in SGOT, SGPT, urea, and creatinine values with $\mathrm{p}>0.05$ for all. Nevertheless, there was an increase in these values (Table 2). However, the decrease in $\mathrm{Hb}$ values obtained a $\mathrm{p}=0.000$. These results indicate $\mathrm{a}$ significant effect of antiretroviral combination therapy on the decrease in $\mathrm{Hb}$ values.

\section{Factors affecting the effectiveness of therapy and decreases in $\mathrm{Hb}$ values}

To determine the factors that influence the effectiveness of therapy and the decrease in $\mathrm{Hb}$ levels due to the use of zidovudine- and tenofovirbased therapy regimens, Chi-square tests were performed. Logistic regression tests were then performed to determine how strong the influences of these factors were.

Sex, weight change, the WHO clinical stage, initial CD4+ cell count, medication obedience, duration of treatment, and use of other therapies were analyzed by Chi-square tests. Chi-square test results are shown in Table 3. These tests were followed by logistic regression tests for factors having a $\mathrm{p}<0.05$ (Table 3).

The results of the logistic regression tests showed that an initial CD4+ cell count $\leq 200$ cells $/ \mathrm{mm}^{3}$ had a five-fold greater effect on increasing the CD4+ cell count when compared with an initial CD4+ > 200 cells $/ \mathrm{mm}^{3}$ (Table 4). Patients receiving zidovudine-based regimens were 5 times more likely to experience $\mathrm{Hb}$ depletion when compared with those receiving a tenofovir-based regimen (Table 5).

\section{DISCUSSION}

In this study, there was a difference in initial CD4+ cell counts (before treatment) and final CD4+ cell counts (after 6 months of therapy) in both antiretroviral combinations. The results of this study are similar to studies conducted in the South Africa that showed antiretroviral combinations influenced changes in CD4+ values with the increase in $\mathrm{CD} 4+$ values for a tenofovir-based regimen $(65 \%)$ higher than for a

Table 1: Comparison of therapeutic effectiveness of zidovudine- and tenofovir-based regimens

\begin{tabular}{|c|c|c|c|c|c|c|}
\hline \multirow[t]{2}{*}{ Variable } & \multicolumn{2}{|c|}{ Zidovudine group } & \multirow[t]{2}{*}{$\mathbf{p}$} & \multicolumn{2}{|c|}{ Tenofovir group } & \multirow[t]{2}{*}{$\mathbf{p}$} \\
\hline & $\mathbf{n}$ & Median (min-max) & & $\mathbf{n}$ & Median (min-max) & \\
\hline $\begin{array}{l}\text { Initial CD4+ } \\
\text { Final CD4+ }\end{array}$ & $\begin{array}{l}75 \\
75\end{array}$ & $\begin{array}{l}169(3-787) \\
246(22-587)\end{array}$ & 0.000 & $\begin{array}{l}53 \\
53\end{array}$ & $\begin{array}{l}238(4-914) \\
313(4-993)\end{array}$ & 0.000 \\
\hline
\end{tabular}


Table 2: Comparison of side effects of zidovudine- and tenofovir-based regimens

\begin{tabular}{llll}
\hline Side effects & $\begin{array}{l}\text { Zidovudine } \\
\text { group (\%) }\end{array}$ & $\begin{array}{l}\text { Tenofovir } \\
\text { group (\%) }\end{array}$ & p \\
\hline Hemoglobin & $9(12.0)$ & $24(45.3)$ & 0.000 \\
$\quad$ Not decreasing & $66(88.0)$ & $29(54.7)$ & \\
$\quad$ Decreasing & $46(61.3)$ & $29(54.7)$ & 0.472 \\
SGOT & $29(38.7)$ & $24(45.3)$ & \\
$\quad$ Increasing & $44(58.7)$ & $26(49.1)$ & 0.368 \\
$\quad$ Decreasing or same & $31(41.3)$ & $27(50.9)$ & \\
SGPT & $42(56.0)$ & $32(60.4)$ & 0.717 \\
$\quad$ Increasing & $33(44.0)$ & $21(39.6)$ & \\
$\quad$ Decreasing or same & & & \\
Urea & & & \\
$\quad$ Increasing & & $26(49.1)$ & 0.720 \\
$\quad$ Decreasing or same & & & \\
Creatinine & & & \\
$\quad$ Increasing & & & \\
$\quad$ Decreasing or same & $35(36.7)$ & $(50.9)$ & \\
\hline
\end{tabular}

Table 3: Factors affecting therapeutic effectiveness and impairment of $\mathrm{Hb}$

\begin{tabular}{|c|c|c|c|}
\hline \multirow[t]{2}{*}{ Variable } & \multicolumn{2}{|l|}{ n (\%) } & \multirow[t]{2}{*}{$\mathbf{p}$} \\
\hline & $\begin{array}{l}\text { Zidovudine } \\
\text { group }\end{array}$ & $\begin{array}{l}\text { Tenofovir } \\
\text { group }\end{array}$ & \\
\hline \multicolumn{4}{|l|}{ Sex } \\
\hline Male & $59(65.6)$ & 31 (57.9) & \multirow[t]{2}{*}{0.014} \\
\hline Female & $16(34.4)$ & $22(42.1)$ & \\
\hline \multicolumn{4}{|l|}{ Age } \\
\hline $18-40$ years & $57(66.7)$ & $44(56.4)$ & \multirow[t]{2}{*}{0.338} \\
\hline 41-60 years & $18(33.3)$ & $9(43.6)$ & \\
\hline \multicolumn{4}{|l|}{ Weight loss } \\
\hline Decreasing & $34(65.4)$ & $18(46.1)$ & \multirow[t]{2}{*}{0.197} \\
\hline Not decreasing & $41(34.6)$ & $35(53.9)$ & \\
\hline \multicolumn{4}{|c|}{ Pulmonary tuberculosis } \\
\hline Yes & $28(37.3)$ & $25(47.2)$ & \multirow[t]{2}{*}{0.266} \\
\hline No & $47(62.7)$ & $28(52.8)$ & \\
\hline \multicolumn{4}{|l|}{ WHO clinical stage } \\
\hline Stadium 1-2 & $55(69.6)$ & $24(40.8)$ & \multirow[t]{2}{*}{0.001} \\
\hline Stadium 3-4 & $20(30.4)$ & $29(59.2)$ & \\
\hline \multicolumn{4}{|c|}{ Initial CD4+cell count } \\
\hline$\leq 200 \mathrm{cell} / \mathrm{mm}^{3}$ & $39(50.6)$ & $28(70.6)$ & \multirow[t]{2}{*}{0.025} \\
\hline$>200 \mathrm{cell} / \mathrm{mm}^{3}$ & $36(49.4)$ & $15(29.4)$ & \\
\hline \multicolumn{4}{|c|}{ Medication obedience } \\
\hline Obedient & $57(54.3)$ & $48(78.3)$ & \multirow[t]{2}{*}{0.034} \\
\hline Disobedient & $18(45.7)$ & $5(21.7)$ & \\
\hline \multicolumn{4}{|c|}{ Treatment duration } \\
\hline$>6$ months & $50(66.7)$ & $25(33.3)$ & \multirow[t]{2}{*}{0.027} \\
\hline 4-6 months & $25(47.2)$ & $28(52.8)$ & \\
\hline \multicolumn{4}{|l|}{ Other therapy } \\
\hline Yes & $62(55.4)$ & $50(81.3)$ & \multirow[t]{2}{*}{0.049} \\
\hline No & $13(46.4)$ & $3(18.8)$ & \\
\hline
\end{tabular}

zidovudine-based regimen (53.1\%) [9]. Likewise, research conducted by Medhanie et al. stated that a tenofovir-based regimen was better at increasing $\mathrm{CD} 4+$ values when compared to a zidovudine-based regimen [10].

In this study, zidovudine had the most common side effects, including anemia. These complaints generally occurred in patients with severe immunosuppression. In this study, patients in both the zidovudine- and tenofovir-based regimens had decreased $\mathrm{Hb}$ values, with the zidovudine group decreasing as much as $82.7 \%$ compared to a decrease of only $50.9 \%$ in the tenofovir group. This finding was consistent with a study by Parkes-Ratanshi et al. (2014), which found anemia in the zidovudine-based regimen (13.0\%) higher compared to the tenofovir or other regimen users (8.7\%) [11]. Zhou et al. also reported a $0.5 \mathrm{~g} / \mathrm{dL}$
Table 4: Predicted influence of several factors on the effectiveness of zidovudine-based regimen therapy

\begin{tabular}{lll}
\hline Variable & $\mathbf{p}$ & OR \\
\hline Antiretroviral combination & 0.621 & $1.28(0.48-3.41)$ \\
Weight changes & 0.183 & $0.54(0.22-1.34)$ \\
Initial CD4+cell count & 0.001 & $5.08(1.96-13.20)$ \\
WHO clinical stage & 0.653 & $0.74(0.20-2.74)$ \\
Patient obedience & 0.504 & $1.61(0.39-6.51)$ \\
Constants & 0.827 & \\
\hline
\end{tabular}

Table 5: Predicted strength of several factors influencing $\mathrm{Hb}$ decrease

\begin{tabular}{lll}
\hline Variable & $\mathbf{p}$ & OR \\
\hline Antiretroviral combination & 0.000 & $5.12(2.12-12.35)$ \\
Weight changes & 0.533 & $0.76(0.32-1.81)$ \\
Initial CD4+cell count & 0.136 & $1.96(0.81-4.76)$ \\
Sex & 0.272 & $1.65(0.67-4.01)$ \\
Constants & 0.192 & 0.53 \\
\hline
\end{tabular}

reduction in $\mathrm{Hb}$ values within 3 months of a zidovudine-based regimen, a finding that contrasted with the tenofovir-based regimen that showed an increase in Hb values [12]. Zidovudine has a toxic effect on the bone marrow by causing a deficiency in thymidine triphosphate, which in turn, inhibits the maturation of erythroid stem cells. This causes the occurrence of red blood cell aplasia (i.e., a reduced number of reticulocytes and $\mathrm{Hb}$ values without hemolysis or blood loss in large quantities) [13].

Antiretroviral treatment also had side effects on the kidneys (nephrotoxic). The antiretroviral agent that plays a role in kidney disorders is tenofovir. Although the overall tenofovir safety was better than with zidovudine. Several studies have shown an association between tenofovir usage and impaired renal function. One study conducted in Brazil with 213 patients found a 1-2\% prevalence of chronic renal impairment in patients taking tenofovir when compared with patients taking zidovudine [14]. Similar to zidovudine, tenofovir was reported as being toxic to mitochondria in renal tubular cells [14].

The increase in CD4+ cell counts was not only due to the use of antiretrovirals alone, but also other influencing factors, such as gender, age, body weight, the presence of pulmonary tuberculosis, the WHO clinical stage, the initial CD4+ cell count, and the patient's obedience [15]. The decrease in $\mathrm{Hb}$ values was also due to several factors that were similar to those affecting the effectiveness of therapy, plus the long-term factors of the treatment, and the usage of other therapies [16]. In this study, patients with an initial CD4+ cell count of $\leq 200$ cells $/ \mathrm{mm}^{3}$ had a greater potential to increase the CD4+ cell count. This result was inversely proportional to the research done by Lubyayi et al., which stated that patients who initiate antiretroviral treatment with higher initial CD4+ cell counts would experience higher increases in CD4+ cell counts [8]. Patients with an initial CD4+ cell count of $<200$ cells $/ \mathrm{mm}^{3}$ have not achieved an increase in CD4+ values, despite taking antiretrovirals for years [17]. However, not all studies have suggested that an early CD4+ cell count will affect the CD4+ cell count increase.

Similar to the Mintohardjo RSAL study conducted at Tigray found a significant increase and a lower risk of immunological failure in patients with a nadir CD $4+\leq 200$ cells $/ \mathrm{mm}^{3}$ when compared with patients with a higher nadir CD4+ cell count [18]. The other study also suggests that patients with very low CD4+ counts at the start of therapy, and a viral load greater than $105 \log 10$ copies/ml, had an 11 -fold increase in CD4+ cell count compared to patients with a higher initial CD4+ cell count [19]. Patients using a combination of zidovudine in this study 
had a 5 times greater risk of decreasing $\mathrm{Hb}$ values. In this study, 13\% of patients were anemic when using zidovudine-containing therapy, and as many as $15 \%$ of the patients had to substitute therapy due to severe anemia. The results of this study were in line with the results of a study conducted by Parkes-Ratanshi et al. (2016) that showed the risk of anemia in patients taking zidovudine was 2.7 times greater than that of patients taking a tenofovir combination [5].

\section{CONCLUSION}

Zidovudine-based regimens and tenofovir-based regimens had similar effectiveness in increasing D4+ cell counts. However, the tendency to cause anemia with the tenofovir-based regimen was lower than with the zidovudine-based regimen. Suggestions for further research include a larger sample of studies with a cohort method, or phase 4 clinical stage trials should be undertaken to ensure the effectiveness and safety of a tenofovir-based regimen as the first-line therapy for people with HIV/AIDS.

\section{REFERENCES}

1. Ministry of Health Republic of Indonesia. Indonesia Health Profile 2014. Jakarta: Ministry of Health Republic of Indonesia; 2015.

2. Nelwan EJ. Adherence to highly active antiretroviral therapy (HAART) in HIV/AIDS patient. Acta Med Indones 2014;46(4):273-4.

3. World Health Organization. Antiretroviral Therapy for HIV Infection in Adults and Adolescents Recommendation for a Public Health Approach 2006 Revision. Geneva: WHO Press; 2006.

4. Agarwal D, Chakravarty J, Chaube L, Rai M, Agrawal NR, Sundar S. High incidence of zidovudine induced anaemia in HIV infected patients in eastern India. Indian J Med Res 2010;132:386-9.

5. van Oosterhout JJ, Mallewa J, Kaunda S, Chagoma N, Njalale Y, Kampira E, et al. Stavudine toxicity in adult longer-term ART patients in Blantyre, Malawi. PLoS One 2012;7(7):e42029.

6. Dong BJ, Ward DJ, Chamberlain LA, Reddy YS, Ebrahimi R, Flaherty JF, et al. Safety and effectiveness of tenofovir/emtricitabine or lamivudine plus ritonavir boosted atazanavir in treatment experienced HIV infected adults at two urban private medical practices. J Antiviral Antiretrovir 2012;4(1):1-5.

7. Machado-Alba JE, González-Santos DM, Vidal-Guitart X. Effectiveness of antiretroviral treatment in patients from Pereira and Manizales. Rev Salud Publica (Bogota) 2011;13(3):492-503.

8. Indonesian Ministry of Health Regulation. Penanggulangan HIV dan AIDS. Jakarta: Indonesian Ministry of Health; 2013.
9. Velen K, Lewis JJ, Charalambous S, Grant AD, Churchyard GJ, Hoffman CJ. Comparison of tenofovir, zidovudine or stavudine as part of first line antiretroviral therapy in a resource limited setting: A cohort study. PLoS One 2013;8(5):e64459.

10. Medhanie EK, Muslimin L, Massi MN, Mangau M. Effectiveness of tenofovir/emtricitabine versus zidovudine/lamivudin in combination with efavirenz in antiretroviral-naïve HIV-infected patients in Eritrea. Int J Pharm Clin Res 2015;7(5):364-7.

11. Parkes-Ratanshi R, Katende D, Levin J, Wakeham K, Heiner G, Kamali A, et al. Development of severe anemia and changes in hemoglobin in a cohort of HIV-infected Ugandan adults receiving zidovudine-, stavudine-, and tenofovir-containing antiretroviral regimens. J Int Assoc Provid AIDS Care 2015;14(5):455-62

12. Zhou J, Jaquet A, Bissagnene E, Musick B, Wools-Kaloustian K, Maxwell N, et al. Short-term risk of anaemia following initiation of combination antiretroviral treatment in HIV-infected patients in countries in sub-Saharan Africa, Asia-Pacific, and central and South America. J Int AIDS Soc 2012;15(1):5.

13. James A, Sudhakar R, Yasaswini B, Manimalika K, Kumar TR, Sivaskumar T. A case report on zidovudine induced anemia and its management in HIV-1 infected patient. Int J Pharm Sci Rev Res 2014;27(2):67-8

14. Tourret J, Deray G, Isnard-Bagnis C. Tenofovir effect on the kidneys of HIV-infected patients: A double-edged sword? J Am Soc Nephrol 2013;24(10):1519-27.

15. Torti C, Prosperi M, Motta D, Digiambenedetto S, Maggiolo F, Paraninfo $\mathrm{G}$, et al. Factors influencing the normalization of CD4+ T-cell count, percentage and CD4+/CD8+ T-cell ratio in HIV-infected patients on long-term suppressive antiretroviral therapy. Clin Microbiol Infect 2012;18(5):449-58.

16. Meidani M, Rezaei F, Maracy MR, Avijgan M, Tayeri K. Prevalence, severity, and related factors of anemia in HIV/AIDS patients. J Res Med Sci 2012;17(2):138-42

17. Lubyayi L, Shkedy Z, Kajungu D, Mwehire D, Kirungi C, Kawuma E, et al. Evolution of CD4 cell counts over time for HIV/AIDS patients on antiretroviral therapy (ART) in Mildmay Uganda. Biomet Biostat Int J 2015;2(2):2-10.

18. Asfaw A, Ali D, Eticha T, Alemayehu A, Alemayuehu M, Kindeya F. CD4 cell count trends after commencement of antiretroviral therapy among HIV-infected patients in Tigray, Northern Ethiopia: A retrospective cross-sectional study. PLoS One 2015;10(3):e0122583.

19. Bishop JD, DeShields S, Cunningham T, Troy SB. CD4 count recovery after initiation of antiretroviral therapy in patients infected with human immunodeficiency virus. Am J Med Sci 2016;352(3):239-44. 